
intercropping with the Japanese bunching onion and parsley. Horticultura Brasileira 26:287-291.

\title{
Yield and gross income of arracacha in monocrop and intercropping with the Japanese bunching onion and parsley
}

\author{
Néstor Antonio Heredia Zárate; Maria do Carmo Vieira; Jerusa Rech; Analice Quast; Bruno Cezar Á \\ Pontim; Rosimeire Pereira Gassi \\ UFGD-FCA, C. Postal 533, 79804-970 Dourados-MS; nahz@terra.com.br
}

\begin{abstract}
The objective of this work was to study the yield performance and to determine the gross income of arracacha (Arracacia xanthorrhiza Bancroft), cultivar Amarela de Carandaí, grown in monoculture as well as in intercropping with the Japanese bunching onion (Allium fistulosum L.), cultivar Todo Ano (A-JBO) and parsley (Petroselinum crispum (Mill.), cultivar Lisa Preferida (A-P). Arracacha and the Japanese bunching onion were vegetatively propagated, while parsley was propagated by seeds. The Japanese bunching onion was first harvested 87 days after the planting (DAP), with resprouts harvested 154 and 212 DAP. Parsley was first harvested 105 days after the sowing (DAS), and, resprouts, 171, 212, and 268 DAS. Arracacha was harvested 268 DAP. At the harvest carried out 212 DAP, the Japanese bunching onion plants in monocrop significantly exceeded those in intercropping in $1.73 \mathrm{~cm}$ height and $0.99 \mathrm{t} \mathrm{ha}^{-1}$ commercial fresh mass (CFM). In parsley, the CFM yield in monocrop significantly exceeded the intercropping figures in 0.63 , 0.66 , and $0.72 \mathrm{tha}^{-1}$ at harvests carried out respectively 171, 212, and 268 DAS. Plant height and CFM of the Japanese bunching onion and parsley increased after every new harvest, except in parsley, for plant height 171 DAS and CFM 268 DAS. No significant differences were found in any of the evaluated characteristics when arracacha as single crop was compared to the A-JBO intercropping arrangement. Nevertheless, the A-P intercropping arrangement significantly reduced all characteristics in relation to the other systems, except for yield of non-commercial arracacha roots. A-JBO intercropping arrangement was viable ( $L E R=1.49$ ) and therefore may be employed by farmers. A-P intercropping, on its turn, was unfeasible $($ LER $=0.97)$.
\end{abstract}

Keywords: Arracacia xanthorrhiza Bancroft, Allium fistulosum L., Petroselinum crispum (Mill.), plant arrangement, cropping system, land equivalent ratio.

\section{RESUMO}

Produção e renda bruta de mandioquinha-salsa em cultivo solteiro e consorciado com cebolinha e salsa

Este trabalho teve como objetivo estudar o desempenho produtivo e determinar a renda bruta obtida a partir do cultivo da mandioquinha-salsa (Arracacia xanthorrhiza Bancroft), cultivar Amarela de Carandaí, em monocultura e consorciada com cebolinha (Allium fistulosum L.), cultivar Todo Ano (MC), e com a salsa (Petroselinum crispum (Mill.), cultivar Lisa Preferida (MS). A propagação da mandioquinha-salsa e da cebolinha foi feita através de mudas, enquanto a salsa foi propagada por sementes. A cebolinha foi colhida 87 dias após o plantio (DAP) e, as rebrotas, 154 e 212 DAP. A salsa foi colhida 105 dias após a semeadura (DAS) e, as rebrotas, 171, 212 e 268 DAS. A mandioquinha-salsa foi colhida 268 DAP. Na colheita realizada 212 DAP, as plantas de cebolinha em cultivo solteiro superaram estatisticamente aquelas consorciadas em $1,73 \mathrm{~cm}$ de altura e $0,99 \mathrm{t} \mathrm{ha}^{-1}$ de massa fresca comercial (MFC). Na salsa, as produções de MFC em monocultura superaram estatisticamente em $0,63,0,66$ e $0,72 \mathrm{t} \mathrm{ha}^{-1}$ a produção do consórcio nas colheitas realizadas 171,212 e 268 DAS, respectivamente. As plantas de cebolinha e salsa tiveram valores maiores para altura e produção de MFC nas colheitas feitas após cada novo corte, exceto em salsa, para a altura de planta 171 DAS e MFC 268 DAS. Não houve diferenças significativas em nenhuma das características avaliadas entre a monocultura de mandioquinha-salsa e o consórcio MC. Já o consórcio MS apresentou, com exceção da produção de raiz não-comercial de mandioquinha-salsa, resultados inferiores aos demais arranjos de cultivo avaliados. O consórcio MC foi considerado viável $($ ERA $=1,49)$ e pode ser utilizado pelos produtores de hortaliças. O consórcio MS, por sua vez, foi inviável ( $\mathrm{RAE}=0,97)$.

Palavras-chave: Arracacia xanthorrhiza Bancroft, Allium fistulosum L., Petroselinum crispum (Mill.), arranjo de plantas, sistema de cultivo, razão de área equivalente.

(Recebido para publicação em 30 de março de 2007; aceito em 18 de março de 2008)

\begin{abstract}
$\mathrm{A}^{\prime}$ rracacha (Arracacia xanthorrhiza Bancroft) gathers important gastronomic, nutritional, and medicinal attributes. Even though, its availability in the local market is restricted, since arracacha is not a traditional vegetable for residents. As consequence, prices are high and the incorporation of arracacha into the menu of people with low income is hampered (Heredia Zárate \& Vieira, 2003). Portz et al. (2006) mention that the area used to grow arracacha is rising in different regions of the country,
\end{abstract}

contributing to increase the supply of this root.

In Mato Grosso do Sul, arracacha, cultivar Amarela de Carandaí, has a vegetative cycle of seven to eight months, yielding between 10 to $15 \mathrm{t} \mathrm{ha}^{-1}$ of marketable roots and between 25 to $35 \mathrm{t} \mathrm{ha}^{-1}$ if all plant parts are considered (leaves, crowns, new sprouts offsets, and non marketable roots). The production cost is around $\mathrm{R} \$ 1.400,00 \mathrm{ha}^{-1}$ (US\$ $1.00=\mathrm{R} \$ 1.64$, June, 2008). If the purpose is industrialization, in which the focus is on dry matter yield and not in marketable roots, production costs can be reduced by increasing plant density and by using semimechanized harvests (Heredia Zárate \& Vieira, 1998).

The Japanese bunching onion (Allium fistulosum L.) is a seasoning highly appreciated by the population. It is grown almost in all Brazilian homes. The plant is perennial, with cylindrical and fistulous dark green leaves, ranging from 0.30 to $0.50 \mathrm{~m}$ in height. It has a small conic bulb, wrapped by a pinkish 
pellicle, and produces tillers, developing into a tussock. Cultivars most widely known are Todo Ano, Futonegui, and Hossonegui (Filgueira, 2000; Heredia Zárate et al., 2003). Harvest begins between 55 and 60 days after planting or between 85 and 100 days after sowing, when plants are from 0.20 to $0.40 \mathrm{~m}$ tall (Filgueira, 2000; Heredia Zárate et al., 2005). Parsley (Petroselinum crispum (Mill.), on its turn, is very important for its commercial use as seasoning and not for the volume or value of commercialization. The first harvest takes place between 50 and 90 days after sowing, when plants are around 10 to $15 \mathrm{~cm}$ tall (Filgueira, 2000; Heredia Zárate et al., 2003).

The increase in production by unit of area is one of the most important reasons to grow plants in intercropping. In vegetables, intercropping allows a better utilization of the available resources, resulting in greater economic revenues (Sullivan, 2001). Tolentino Júnior et al. (2002), studying the productivity of arracacha, cultivar Amarela de Carandaí, intercropped with lettuce, cultivar Grand Rapids, and beet, cultivar Tal Top Early Wonder, concluded that the intercropping arrangement using the three crops outyielded the monoculture. Nevertheless, the Land Equivalent Ratio (LER) for commercial root yield was 0.87 when arracacha and beet were intercropped, and 1.1 for arracacha and lettuce.

Heredia Zárate et al. (2005), studying yield and the economic revenue of the Japanese bunching onion, cultivar Todo Ano (JBO), and coriander, cultivar Asteca (C), in monoculture and intercropping, displaying each vegetable in combinations of three- and four-row sets per seedbed in intercropping, observed that the production of fresh mass in coriander significantly increased in $1.4 \mathrm{t} \mathrm{ha}^{-1}(41,2 \%)$ under monoculture and with four lines $\left(\mathrm{C}_{4}\right)$ in comparison to three lines $\left(3.5 \mathrm{t} \mathrm{ha}^{-1}\right)$. LER of the intercropping using the Japanese bunching onion and coriander were $21 \%$ $\left(\mathrm{JBO}_{3} \mathrm{C}_{4}\right)$ and $56 \%\left(\mathrm{JBO}_{4} \mathrm{Co}_{3}\right)$ superior to the monocultures. The intercropping $\mathrm{JBO}_{3} \mathrm{C}_{4}$ resulted disadvantageous and would lead to a loss in the gross income of $\mathrm{R} \$ 99.4 \mathrm{ha}^{-1}$, notwithstanding the LER higher than 1.0. On the other hand, the intercropping $\mathrm{JBO}_{4} \mathrm{Co}_{3}$ would lead to a revenue of $\mathrm{R} \$ 777.8 \mathrm{ha}^{-1}$. Heredia Zárate et al. (2003), studying intercropping the Japanese bunching onion, cultivar Todo Ano, and parsley, cultivar Lisa, observed that the average yield of the Japanese bunching onion and parsley in monoculture had significant increases of respectively 1.3 and $2.4 \mathrm{t} \mathrm{ha}^{-1}$ in fresh mass, and of $0.2 \mathrm{t}$ $\mathrm{ha}^{-1}$, for both plants, in dry mass, when compared to intercropping. Nevertheless, LER in intercropping was 1.4 for fresh mass yield, with gross income increasing $25.1 \%$ ( $\mathrm{R} \$ 7,830.00$ $\left.\mathrm{ha}^{-1}\right)$ and $74.9 \%(\mathrm{R} \$ 16,740.00)$ when compared to the income of the Japanese bunching onion and parsley in monoculture, respectively.

Considering the importance of evaluating the regional performance of vegetable crops and also the lack of reports on intercropping arracacha with parsley and the Japanese bunching onion, the present work aimed at studying the yield and the gross income of arracacha in monoculture and in intercropping with the Japanese bunching onion and parsley, in Dourados.

\section{MATERIAL AND METHODS}

The work was carried out at the Horticultural Garden of Medicinal Plants, in the Experimental Farm of Agrarian Sciences, Federal University of Grande Dourados, in Dourados, Mato Grosso do Sul State, from March 19 to December 12, 2006. The soil at the garden is Rhodic Hapludox, with clayish texture, and the following chemical characteristics: $\mathrm{pH}=5.5\left(\mathrm{CaCl}_{2}\right)$; Organic matter $=34.0 \mathrm{dm}^{-3} ; \mathrm{P}=36.0$ $\mathrm{mg} \mathrm{dm}{ }^{-3} ; \mathrm{K}, \mathrm{Ca}$ and $\mathrm{Mg}=6.6,56.0$ and $22.6 \mathrm{mmol} \mathrm{dm}_{\mathrm{c}}^{-3}$, respectively.

The experiment was designed in completely randomized blocks, with five treatments and four replications. Treatments corresponded to monocultures of arracacha (A), the Japanese bunching onion (JBO), and parsley $(\mathrm{P})$, as well as the intercropping of arracacha with the Japanese bunching onion (A-JBO) and with parsley (A-P). The experimental plot had a total area of $3.6 \mathrm{~m}^{2}$ (1.5 × $2.4 \mathrm{~m}$, width/length) and a work area of $2.4 \mathrm{~m}^{2}(1.0 \times 2.0 \mathrm{~m}$, width/length). The Japanese bunching onion and parsley plots, both in monoculture and in intercropping, had four rows ( $25.0 \mathrm{~cm}$ between rows), with 24 plants per row $(10 \mathrm{~cm}$ between plants) for the Japanese bunching onion, 48 plants per line $(5.0 \mathrm{~cm}$ between plants) for parsley. Arracacha plots, both in monoculture and in intercropping had two rows ( $50.0 \mathrm{~cm}$ between rows), with 12 plants per row $(20 \mathrm{~cm}$ between plants). In intercropping, each row of arracacha was inserted between every two rows of the Japanese bunching onion or parsley, in each end.

The Japanese bunching onion and arracacha were vegetatively propagated, while parsley was propagated by seeds. The Japanese bunching onion seedlings were prepared a day before planting, when tillers were harvested and cleaned, roots and dried sheaths were removed, and leaves were cut to leave 5-cm stubs. Seedlings were planted leaving uncovered almost $3 \mathrm{~cm}$ of the stub. Arracacha offsets were supplied by a farmer from Manhuaçu, Minas Gerais State. Offsets were selected, transversally cut at the base, and visually clustered in four groups according to the offset average mass, as follows: group $1=15.9 \mathrm{~g} ; 2=9.7 \mathrm{~g} ; 3=7.3 \mathrm{~g}$, and $4=$ $6.0 \mathrm{~g}$. To optimize offset use, each group was used to plant one replication. Offsets were planted leaving uncovered almost $1.0 \mathrm{~cm}$ of the pseudostem. Plants were watered using sprinkling irrigation, aiming at keeping the soil at 65 to $70 \%$ of field capacity, which resulted in 2day irrigation shifts. Weeds were controlled by hoeing between rows and hand-picking within the row.

The Japanese bunching onion and parsley were harvested every time leaves started loosing shine. Three harvests were carried out in the Japanese bunching onion, the main harvest 87 days after planting (DAP) and, the following, 154 and 212 DAP. Parsley was harvested four times: 105, 171, 212, and 268 days after sowing (DAS). For harvesting, plants of the Japanese bunching onion were cut at soil level, 
while plants of parsley were cut just above the new sprouts. At each harvest, plant height and fresh commercial yield were evaluated. All healthy leaves, longer than $15 \mathrm{~cm}$, in the Japanese bunching onion, and $12 \mathrm{~cm}$, in parsley, were considered commercial. The harvest of arracacha was carried out 268 DAP, when plants presented more than $50 \%$ of senescent leaves. In arracacha, plant height, and the fresh mass of leaves, offsets, crowns, commercial $(>25.0 \mathrm{~g})$ and non commercial roots $(<25.0 \mathrm{~g})$ were evaluated.

Data on the monoculture and intercropped systems were submitted to the analysis of variance and tested by $\mathrm{F}$ test, at 5\% probability. Significant differences in the cropping systems were identified using the Tukey test, also at $5 \%$ probability. Intercropping was assessed by means of the Land Equivalent Ratio (LER) (Caetano et al., 1999): LER $(\mathrm{A}-\mathrm{JBO})=(\mathrm{Ai}) \cdot(\mathrm{Am})^{-1}+$ $(\mathrm{JBOi}) \cdot(\mathrm{JBOm})^{-1}$ and LER $(\mathrm{A}-\mathrm{P})=$ (Ai). $(\mathrm{Am})^{-1}+(\mathrm{Pi}) \cdot(\mathrm{Pm})^{-1}$, in which $\mathrm{Ai}=$ yield of fresh mass of arracacha commercial roots in a given intercropping; $\mathrm{Am}=$ yield of fresh mass of arracacha commercial roots in monoculture; JBOi $=$ yield of commercial leaves of the Japanese bunching onion in intercropping; JBOm $=$ yield of commercial leaves of the Japanese bunching onion in monoculture; $\mathrm{Pi}=$ yield of commercial leaves of parsley in intercropping; and $\mathrm{Pm}=$ yield of commercial leaves of parsley in monoculture. The intercropping was validated by estimating the gross income. For this purpose, average fresh masses and retail prices, as well as prices paid to farmers were obtained. The average fresh mass of the Japanese bunching onion bunch was $63.6 \mathrm{~g}$, ranging from 56.1 to $81.0 \mathrm{~g}$, while the average fresh mass of parsley bunches was 64.9 , varying between 63.1 and $67.4 \mathrm{~g}$. Prices of bunches for both vegetables at the retail market varied from $R \$ 0.40$ to $R \$ 0.50$. According to dealtehe ers of the free market in Dourados, MS, the price paid to farmers was $\mathrm{R} \$ 0,25$. For arracacha, the price per $\mathrm{kg}$ of commercial roots at the retail market was $\mathrm{R} \$ 3.50$, while farmers received $R \$ 1.50$. The gross income was

Table 1. Plant height and commercial fresh mass of the Japanese bunching onion in monoculture and intercropped with arracacha, in three harvests (altura de planta e massa fresca comercial de cebolinha em monocultura e consorciada com mandioquinha-salsa, em três colheitas) Dourados, UFGD, 2006.

\begin{tabular}{|c|c|c|c|c|c|c|}
\hline \multirow{2}{*}{$\begin{array}{l}\text { Cropping } \\
\text { system }\end{array}$} & \multicolumn{3}{|c|}{ Plant height $(\mathrm{cm})$} & \multicolumn{3}{|c|}{ Commercial fresh mass $\left(\mathrm{t} \mathrm{ha}^{-1}\right)$} \\
\hline & $87^{1}$ & $154^{1}$ & $212^{1}$ & $87^{1}$ & $154^{1}$ & $212^{1}$ \\
\hline Monoculture & $16,66 a$ & $18,25 a$ & $19,98 a$ & $0,52 a$ & $1,49 a$ & $2,01 a$ \\
\hline Intercropping & $16,78 a$ & $17,63 a$ & $18,25 b$ & $0,58 a$ & $0,98 a$ & $1,02 b$ \\
\hline $\mathrm{CV}(\%)$ & 1,54 & 1,68 & 1,15 & 22,27 & 25,44 & 33,97 \\
\hline
\end{tabular}

Means followed by the same letter in the columns did not differ significantly from each other by the $\mathrm{F}$ test, $\mathrm{p}<0.05$ (médias seguidas de mesma letra nas colunas não diferem significativamente entre si pelo teste $\mathrm{F}, \mathrm{p}<0,05) ;{ }^{1}$ Days after planting.

Table 2. Plant height and commercial fresh mass of parsley in monoculture and intercropped with arracacha, in four harvests (altura de planta e massa fresca comercial da salsa em monocultura e consorciada com mandioquinha-salsa, em quatro colheitas). Dourados, UFGD, 2006.

\begin{tabular}{|c|c|c|c|c|c|c|c|c|}
\hline \multirow{2}{*}{$\begin{array}{l}\text { Cropping } \\
\text { system }\end{array}$} & \multicolumn{4}{|c|}{ Plant height $(\mathrm{cm})$} & \multicolumn{4}{|c|}{ Commercial fresh mass $\left(\mathrm{t} \mathrm{ha}^{-1}\right)$} \\
\hline & $105^{1}$ & $171^{1}$ & $212^{1}$ & $268^{1}$ & $105^{1}$ & $171^{1}$ & $212^{1}$ & $268^{1}$ \\
\hline Monoculture & $16,47 a$ & $14,40 a$ & $17,28 a$ & $18,19 a$ & $2,66 a$ & $3,46 a$ & $3,88 a$ & $2,73 a$ \\
\hline Intercropping & $16,20 \mathrm{a}$ & $14,74 a$ & $17,31 \mathrm{a}$ & $17,95 a$ & $2,61 a$ & $2,83 \mathrm{~b}$ & $3,22 b$ & $2,01 \mathrm{~b}$ \\
\hline CV (\%) & 1,69 & 4,25 & 3,70 & 6,79 & 16,28 & 10,55 & 9,76 & 9,43 \\
\hline
\end{tabular}

Means followed by the same letter in the columns did not differ significantly from each other by the $\mathrm{F}$ test, $\mathrm{p}<0.05$ (médias seguidas de mesma letra nas colunas não diferem significativamente entre si pelo teste $\mathrm{F}, \mathrm{p}<0,05)$; ${ }^{1}$ Days after sowing.

obtained by multiplying the estimate of production per hectare in each cropping system by the price paid to farmers.

\section{RESULTS AND DISCUSSION}

Plant height and commercial fresh mass of the Japanese bunching onion was not significantly altered by the cropping system, as evaluated in the harvests carried out 87 and 154 DAP. In the harvest carried out 212 DAP, plants in monoculture significantly exceeded those in intercropping in $1.73 \mathrm{~cm}$ height and $0.99 \mathrm{tha}^{-1}$ of commercial fresh mass (Table 1). These results agrees with Heredia Zárate (1988), quoted by Harder (2004) and Harder et al. (2005) who states that plants can present growing and morphological characteristic rates well defined by environmental factors, but with a responding pattern dependent on the genetic constituent.

In parsley, treatments did not significantly influence height in any harvest. On the other hand, the yield of commercial fresh mass in monoculture significantly exceeded what was observed in intercropping in $0.63,0.66$, and $0.72 \mathrm{t} \mathrm{ha}^{-1}$ in the harvests carried out 171, 212, and 268 DAS, respectively (Table 2). These results are related to Larcher (2000) hypothesis of the selfregulation ability of ecological systems, based on the equilibrium of the interference relationship. That happens due to alterations in the source-sink balance induced by cropping conditions (Larcher, 2000; Benincasa, 2003; Harder et al., 2005).

Plant height and commercial yield increased in the Japanese bunching onion and parsley after every new harvest, except in parsley for plant height 171 DAS, and yield 268 DAS. These results corroborate that there are differences in the plant potential ability for self-regulation in relation to the equilibrium of the interference relationship (Larcher, 2000). In the case of harvesting resprouts, plant ability for self-regulation is influenced by its response to the previous harvest (Harder et al., 2005). These results corroborate Filgueira (2000) and Heredia Zárate et al. (2005) observations that the Japanese bunching onion resprouts can be used as a new harvest. Moreover, they are even more relevant if it is considered 
Table 3. Morphological characteristics of arracacha in monoculture and intercropped with the Japanese bunching onion and Parsley (características morfológicas de mandioquinhasalsa em monocultura e consorciada com cebolinha e salsa). Dourados, UFGD, 2006.

\begin{tabular}{|c|c|c|c|c|c|c|}
\hline \multirow[b]{2}{*}{$\begin{array}{l}\text { Cropping } \\
\text { system }\end{array}$} & \multirow[b]{2}{*}{$\begin{array}{l}\text { Plant } \\
\text { height } \\
\text { (cm) }\end{array}$} & \multicolumn{5}{|c|}{ Fresh mass $\left(\mathrm{t} \mathrm{ha}^{-1}\right)$} \\
\hline & & Leaves & Offsets & Crown & $\begin{array}{c}\text { Commercial } \\
\text { roots }\end{array}$ & $\begin{array}{c}\text { Non- } \\
\text { commercial } \\
\text { roots }\end{array}$ \\
\hline Monoculture & $21,00 \mathrm{a}$ & $6,22 a$ & $4,36 a$ & $4,49 a$ & $8,04 a$ & $2,15 \mathrm{a}$ \\
\hline A-JBO ${ }^{1}$ & 21,89 a & $6,85 a$ & $4,39 a$ & $3,36 a b$ & $6,81 a$ & $1,96 \mathrm{a}$ \\
\hline$A-P^{2}$ & $16,14 \mathrm{~b}$ & $1,38 \mathrm{~b}$ & $1,25 \mathrm{~b}$ & $2,43 \mathrm{~b}$ & $1,02 \mathrm{~b}$ & $1,43 \mathrm{a}$ \\
\hline$\overline{C V}(\%)$ & 5,56 & 35,91 & 32,30 & 21,75 & 26,62 & 33,24 \\
\hline
\end{tabular}

Means followed by the same letter in the columns did not differ significantly from each other by the $\mathrm{F}$ test, $\mathrm{p}<0.05$ (médias seguidas de mesma letra nas colunas não diferem significativamente entre si pelo teste $\mathrm{F}, \mathrm{p}<0,05) ;{ }^{1} \mathrm{~A}-\mathrm{JBO}$ : intercropping of arracacha and the Japanese bunching onion (plantio consorciado de mandioquinha-salsa e cebolinha); ${ }^{2} \mathrm{~A}-\mathrm{P}$ : intercropping of arracacha and parsley (plantio consorciado de mandioquinha-salsa a salsa).

Table 4. Producer gross income considering the commercial yield of arracacha, the Japanese bunching onion, and parsley, in monoculture and intercropped. (renda bruta do produtor considerando a produção comercial de mandioquinha-salsa, cebolinha e salsa, em monocultura e em consórcio). Dourados, UFGD, 2006.

\begin{tabular}{|c|c|c|c|c|c|c|}
\hline \multirow{2}{*}{$\begin{array}{l}\text { Cropping } \\
\text { system }\end{array}$} & \multirow{2}{*}{ Vegetable } & \multirow{2}{*}{$\begin{array}{l}\text { Commercial } \\
\text { fresh mass } \\
\left(\mathrm{t} \mathrm{ha}^{-1}\right)\end{array}$} & \multirow{2}{*}{$\begin{array}{l}\text { Bunches }^{1} \\
\text { (no. ha-1) }^{-1}\end{array}$} & \multirow{2}{*}{ LER $^{2}$} & \multicolumn{2}{|c|}{ Gross income $\left(R \$ h^{-1}\right)^{3}$} \\
\hline & & & & & Per crop & Total \\
\hline \multirow{3}{*}{ Monoculture } & Arracacha & 8,04 & & 1,00 & $12.060,00$ & $12.060,00$ \\
\hline & $\begin{array}{l}\text { Bunching } \\
\text { onion }\end{array}$ & 4,02 & 63.207 & 1,00 & $15.801,75$ & $15.801,75$ \\
\hline & Parsley & 12,73 & 196.147 & 1,00 & $49.036,75$ & $49.036,75$ \\
\hline \multirow{4}{*}{ Intercropping } & Arracacha & 6,81 & & & $10.215,00$ & \\
\hline & $\begin{array}{l}\text { Bunching } \\
\text { onion }\end{array}$ & 2,58 & 40.566 & 1,49 & $10.141,50$ & $20.356,50$ \\
\hline & Arracacha & 1,02 & & & $1.530,00$ & \\
\hline & Parsley & 10,76 & 164.406 & 0,97 & $41.101,50$ & $42.631,50$ \\
\hline
\end{tabular}

${ }^{1}$ The number of bunches was estimated by divinding yield by the average mass of commercial bunches (o número de maços foi estimado divivindo-se a produtividade pela massa média dos maços comerciais; ${ }^{2}$ LER: Land equivalent ratio (RAE: razão de área equivalente); ${ }^{3} \mathrm{Gross}$ income estimated by multiplying yield by the price paid to farmers, as informed by dealers at the free-market of Dourados, in January 8, 2007; US\$ 1,00 = R\$ 1,64, June 13, 2008 (renda bruta calculada multiplicando-se a produtividade pelo preço pago aos produtores, de acordo com os valores informados pelos vendedores da feira livre de Dourados, em $8 \mathrm{de}$ janeiro de 2007; US\$1,00 = R \$1,64, 13 de junho de 2008).

that the time lag between harvest and sprouts, both to the Japanese bunching onion and parsley, was around $50 \%$ of the time needed for the first harvest. It is supposed that resprouts grow faster than the initial sprouts because during resprouting plants do not need to divert assimilates to root development (Harder et al., 2005).

The intercropping of arracacha with the Japanese bunching onion did not significantly alter any of the evaluated characteristics when compared to arracacha grown in monoculture. Nevertheless, when arracacha was feasible, once its LER was 1.49. On the other hand, the A-P combination was not viable, with LER $=0.97$ (Table 4). These results agree with Trenbath (1975), quoted by Harder (2004), who reports that the careful choice of the crops is essential to provide maximum exploitation advantages in intercropping. It was observed that the A-JBO intercropping was the best arrangement for farmers, if the objective is to combine an increase in the revenue with a reasonable production of arracacha roots. When compared to arracacha in monoculture, the A-JBO system yielded $84.7 \%$ of commercial arracacha roots and resulted in an income increase of $16.9 \%(\mathrm{R} \$ 8,296.50$ $\left.\mathrm{ha}^{-1}\right)$. In the A-P system, notwithstanding increases of 253.5 and $109.4 \%$ in the gross income in relation to respectively arracacha in monoculture and intercropped with the Japanese bunching onion, the production of arracacha commercial roots was only $12.7 \%$ of the highest arracacha yield in the experiment, observed for arracacha in monoculture. Moreover, to parsley producers, intercropping was not profitable, once it would result on a loss of $15.0 \%$ (R\$ 6,405.25) of gross income, when compared to the monoculture ( $\mathrm{R} \$$ 49,036.75).

Based on Land Equivalent Ratio and gross income, the conclusion is that, for arracacha producers, intercropping arracacha with bunching onion is feasible and can be used by farmers, unlike intercropping with parsley, which was disadvantageous.

\section{ACKNOWLEDGEMENTS}

To CNPq (The National Council for Scientific and Technological Development), for the scholarships granted, and to the FUNDECT-MS, for the financial support. Néstor Antonio Heredia Zárate and Maria do Carmo Vieira hold CNPq fellowships in Productivity in Research; Jerusa Rech holds a CNPq scholarship for Scientific Initiation.

\section{REFERENCES}

According to Santos (1998), two crops are suitable for intercropping if LER is over 1.0. Thus, the intercropping arrangement A-JBO must be considered 
CAETANO LCS; FERREIRA JM; ARAÚJO M. 1999. Produtividade da alface e cenoura em sistema de consorciação. Horticultura Brasileira 17: 143-146.

FILGUEIRA FAR. 2000. Novo manual de olericultura: agrotecnologia moderna na produção e comercialização de hortaliças. Viçosa: UFV. 402p.

HARDER WC. 2004. Produção e renda bruta de rúcula (Eruca sativa Mill.) 'Cultivada' e de almeirão (Cichorium intybus L.) 'Amarelo', em cultivo solteiro e consorciado. Dourados: UFMS. 26p. (Tese mestrado).

HARDER WC; HEREDIA ZÁRATE NA; VIEIRA MC. 2005. Produção e renda bruta de rúcula (Eruca sativa Mill.) 'Cultivada' e de almeirão (Cichorium intybus L.) 'Amarelo', em cultivo solteiro e consorciado. Ciência e Agrotecnologia 29: 775-785.
HEREDIA ZÁRATE NA; VIEIRA MC. 1998. Produção e uso de hortaliças amídicas para consumo humano e para alimentação de frangos de corte. In: SIMPÓSIO INTERNACIONAL SOBRE AGRICULTURA SUSTENTABLE, 1. Palestra... Pedro Juan Caballero - Paraguai. p. 1-7.

HEREDIA ZÁRATE NA; VIEIRA MC. 2003. Hortas: conhecimentos básicos. Dourados: UFMS. 57p.

HEREDIA ZÁRATE NA; VIEIRA MC; WEISMANN M; LOURENÇÃO ALF. 2003. Produção e renda bruta de cebolinha e de salsa em cultivo solteiro e consorciado. Horticultura Brasileira 21: 578-581.

HEREDIAZÁRATE NA; VIEIRA MC; ONO FB; SOUZA CM. 2005. Produção e renda bruta de cebolinha e de coentro, em cultivo solteiro e consorciado. Semina: Ciências Agrárias 26:141-146.
LARCHER W. Ecofisiologia vegetal. 2000. São Carlos: RiMa Artes e Textos. 531p.

PORTZ A; MARTINS CAC; LIMA, E; ZONTA E. 2006. Teores e acúmulo de nutrientes durante o ciclo da mandioquinha-salsa em função da aplicação de nitrogênio, fósforo e potássio. Horticultura Brasileira 24: 329-333.

SULLIVAN P. Intercropping principles and production practices. 2001. Disponível em http: //www.attra.org/attra-pu/ intercrop.html\#abstratNational. Acessado em 3 de setembro de 2003.

TOLENTINO JÚNIOR CF, HEREDIA ZÁRATE NA, VIEIRA MC. 2002. Produção da mandioquinha-salsa consorciada com alface e beterraba. Acta Scientiarum: Agronomy 24: 1447-1454. 